\title{
SASKATCHEWAN REVISITED
}

\section{by Mary M. Tremaine, University College of Medicine, Omaha, Nebraska}

Blue Jay readers may be interested in "birding impressions" of an outsider in the province. I first visited Saskatchewan in 1961, and in spite of the drought had a thoroughly good time. This year I planned to come in July, not nearly as good as June for birds, but the best I could manage. I particularly wanted to visit the Battlefords area and drive the Hanson Lake Road all the way; on the previous visit I had fallen in love with the Nipawin Forest Reserve, and I expected the Hanson Lake Road to offer more of the same country.

Because of my previous visit, I found it interesting to compare the abundance of certain species of birds with my 1961 observations. Hawks, I found, were noticeably scarce throughout the province in contrast to my experience on the 1961 visit. I was also glad to look again for prairie species like the Chestnut-collared

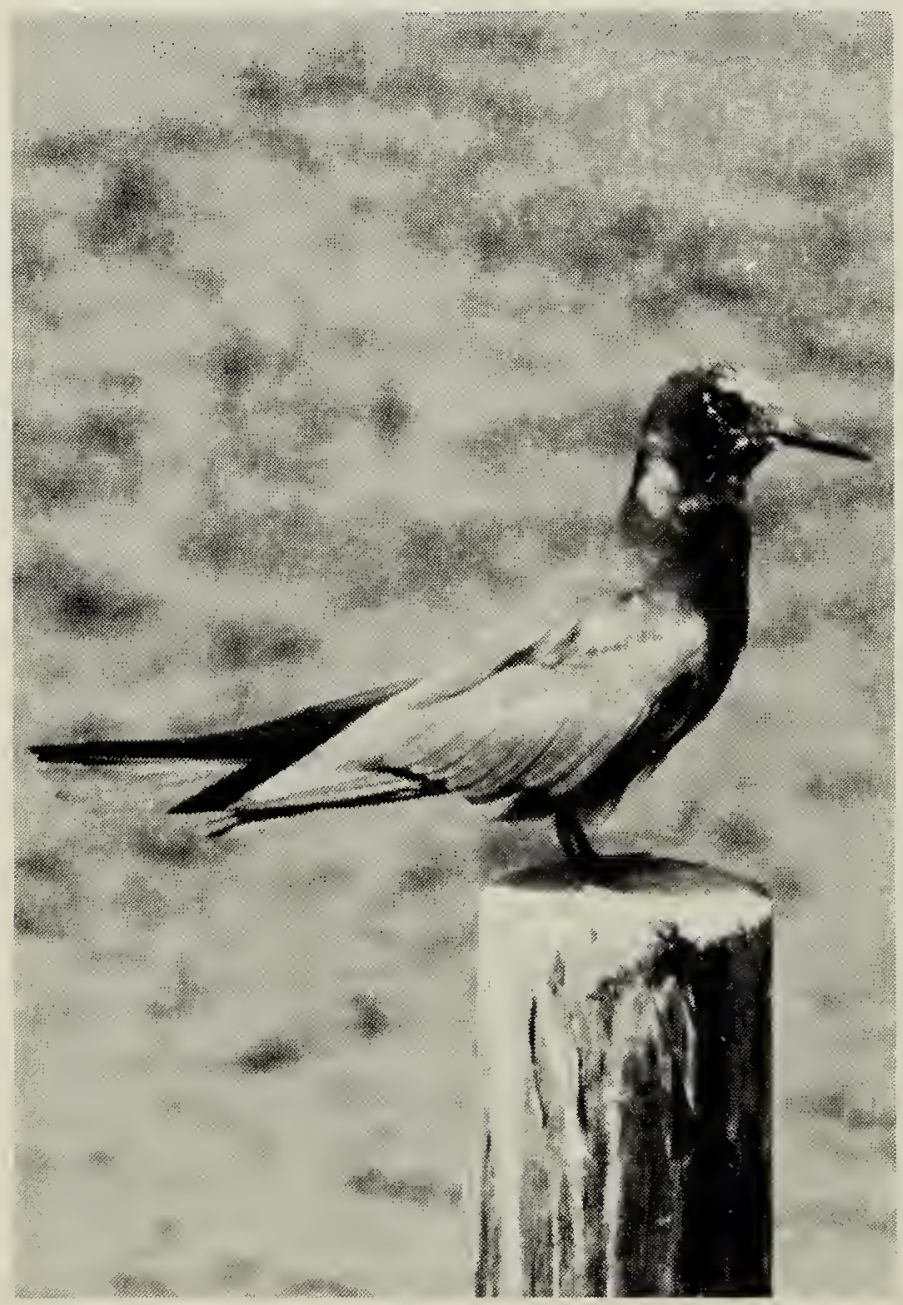

Photo by Mary M. Tremaine

Moulting Black Tern
Longspurs and the Sprague's Pipits, which I found near the beautiful Qu'Appelle Valley. North of Last Mountain Lake a pair of Short-eared Owls sat on a fence for us; I had never seen these in breeding plumage, so it was a real treat. I was so bemused that I forgot to use the camera on the seat beside me!

When I was in Saskatoon I visited the Medical School and met Dr. Houston. He called his wife, and out we went for a fine lunch with wonderful "bird talk". Saskatchewan is fortunate to have these fine people. I was a perfect stranger, but from their hospitality, one would have thought I was a best friend!

Because of car trouble, our stop at the Battleford Provincial Park was even longer than planned, and we got a good list of birds. In addition, we had time to watch the behaviour of such birds as the Franklin's Gulls that were already flocking. One evening there was a hatch of insects along a gravel road; the Franklins fed on the wing in the columns of insects (midges?) - it was at sunset, and a beautiful, exciting hour.

Highway 26 took us north of Spruce Lake and on this road we found a deep, U-shaped valley with sprucemuskeg type habitat right in the middle of typical farming country; we named it Glacier Gully. I was just explaining to my companion that this was the kind of country where we might hope to see a Bonaparte's Gull when a spot of white on top of a spruce tree caught my eye. Out came the binoculars and telescope, and there it was as advertised! It was indeed a Bonaparte's Gull in the full glory of breeding plumage. How was this valley formed, and why was its vegetation what one would expect to find farther north?

We visited the Meadow Lake Provincial Park and Flotten Lake and then I went on from Prince Albert to 
Sandy Lake and Duck Lake. The latter was crowded with birds, just as it was when I was here in 1961. I wonder why this lake can carry such a high density of nesting ducks. I saw nothing unusual, but enjoyed myself immensely. Travelling east to Melfort on the small gravel roads yielded many ponds and many ducks -one Canvasback had 20 ducklings, all Cans and all exactly the same size. I thought there must have been two broods; can you imagine one duck managing to hatch 20 ducklings? I sat for three hours trying to photograph them, but the female was wily, and knew there was something in that brown canvas covered with grass and reeds. Nevertheless I had a fine time watching the youngsters even though I got no good pictures. My legs subsequently had a good rash from the bird Schistosome cereariae in the water. Are ducks in Saskatchewan heavily parasitized with these flukes?

The last lap of my trip was the Hanson Lake Road, and it took me a week to drive to Flin Flon because there were so many beautiful places and birds to see. In a trip such as this summer's expedition into Saskatchewan one gains a great deal by observation of bird distribution and habitat; this aspect interests me greatly. The records of birds seen have been sent to the Blue Jay for its Saskatchewan bird files, including records of rare species like the Parula Warbler and Harlequin Duck that should be evaluated by Saskatchewan bird men. These unusual sightings were a great thrill for me, but no more enjoyable than the day-to-day opportunity to see birds in their natural habitat. I had a lot for fun, for example, photographing sapsuckers at a feeding tree which was visited by hummingbirds and butterflies as well. The hummingbirds were never on the tree at the same time as the sapsuckers, and fought vigorously among themselves for the best feeding hole. The male sapsucker evidently decided the old holes weren't producing well enough and spent almost an hour methodically producing new holes; the female busily gathered insects but the male

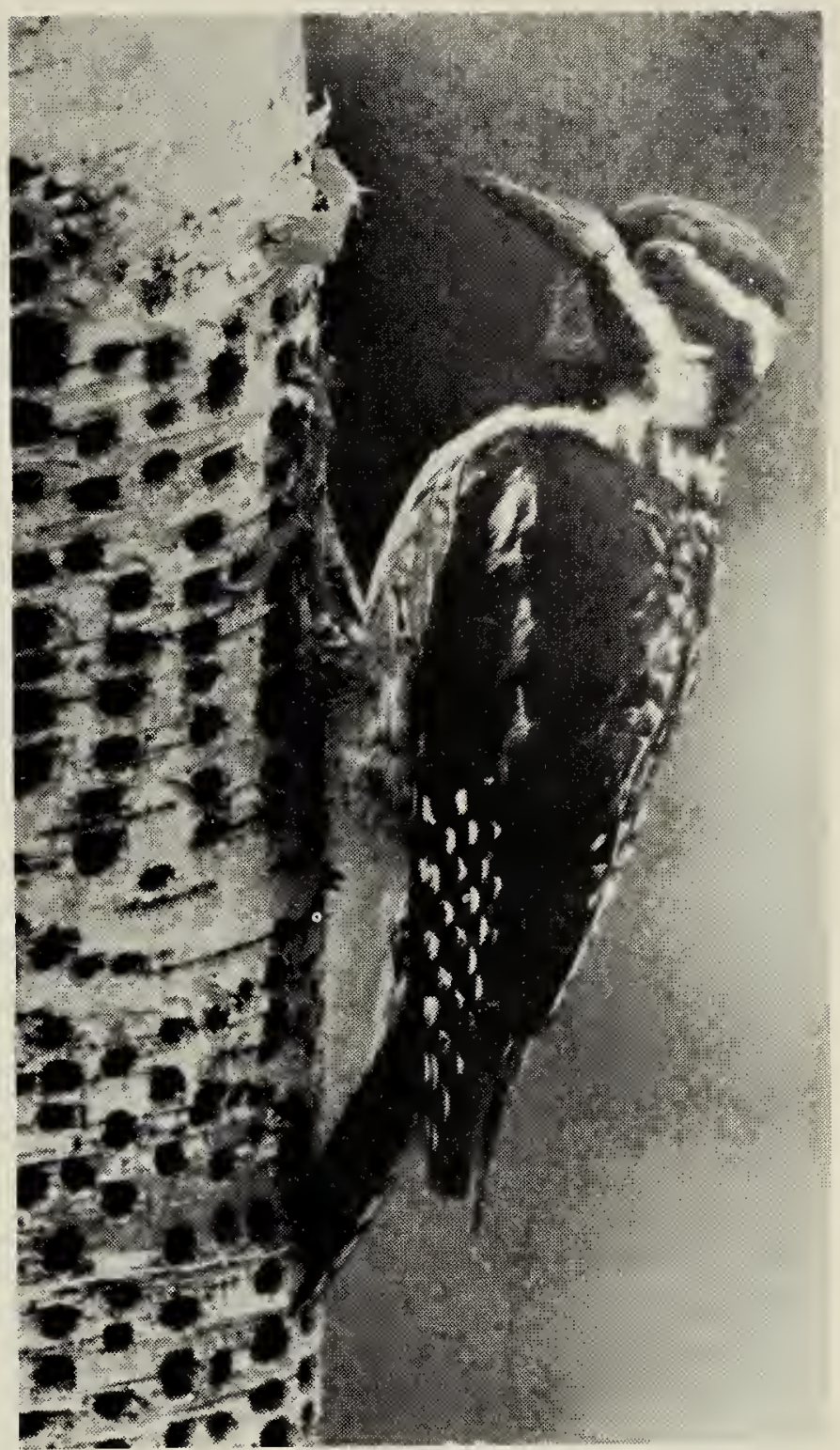

Photo by Mary M. Tremaine

Male Yellow-bellied Sapsucker

always left the tree while she was there - curious behaviour.

Some of the changes that I noted in Saskatchewan during this trip of course disturbed me. I was concerned, for example, at the use of DDT fog in the campsites every night; does it have to be DDT? The birds weren't abundant in the campsites as they were in my previous visit; fishermen complained that the lakes by the campsites had no fish. Is there a connection? I didn't see any insecticide being used in the Nipawin-Hanson Lake area, but it was certainly heavily used on the prairies. These campsites were very short on bird life, compared with my previous visit. I like to camp because I like to sit and have my coffee and watch the birds. This year I just drank my coffee, most of the time. 